\title{
A Computational Model of Electrophysiological Properties of Cardiomyocytes
}

\author{
Ivanushkina N. G. ${ }^{1}$, Ivan'ko E. O. ${ }^{1}$, Prokopenko Yu. $V .^{1}$, Redaelli $A .^{2}$, Tymofieiev V. $I^{1}{ }^{1}$, Visone $R .^{2}$ \\ ${ }^{1}$ National Technical University of Ukraine "Igor Sikorsky Kyiv Polytechnic Institute", Ukraine \\ ${ }^{2}$ Politecnico di Milano, Italy \\ E-mail: n.ivanushkina@gmail.com
}

\begin{abstract}
Introduction. The method of electrical analogies for the analysis of bioelectric dynamic processes in cardiomyocytes is used in the study. This method allows for replacing investigation of phenomena in nonelectrical systems by research of analogous phenomena in electrical circuits. The investigation of time processes in cardiac cells is based on the solution of the system of ordinary differential equations for an electrical circuit. Electrophysiological properties of cardiomyocytes such as refractory period, maximum capture rate and electrical restitution are studied.

Mathematical modeling. Computational simulation of the action potential and currents for $\mathrm{K}^{+}, \mathrm{Na}^{+}$, $\mathrm{Ca}^{2+}$ ions in cardiomyocytes is performed by using the parallel conductance model. This model is based on the assumption of the presence of independent ion channels for $\mathrm{K}^{+}, \mathrm{Na}^{+}, \mathrm{Ca}^{2+}$ ions, as well as leakage through the membrane of cardiac cell. Each branch of the electrical circuit reflects the contribution of one type of ions to total membrane current.

Results. The obtained electrical restitution curves for ventricular and atrial cardiomyocytes are presented in the paper. The proposed model makes it possible to identify the areas with the maximum slope on the restitution curves, which are crucial in the development of cardiac arrhythmias. Dependences of calcium current on stimulation frequency for atrial and ventricular cardiomyocytes are obtained. Analysis of the kinetics of calcium ions under various protocols of external influences can be useful for predicting the contractile force of cardiomyocytes.

Conclusion. The results of calculations can be used to interpret the experimental results obtained in investigations of cardiomyocytes using the "laboratory on a chip" technology, as well as in the design of new experiments with cardiomyocytes for drug screening, cell therapy and personalized studies of heart diseases.
\end{abstract}

Key words: method of electrical analogies; cardiomyocyte; action potential; parallel conductance model; electrical restitution curve; lab-on-chip platform

\section{Introduction}

The method of dynamic analogies is widely used for a long time as a basis for interdisciplinary research of technical systems and physical models in medicine, biology, ecology [1-4]. The concept of biomimetic design [5] is the development of dynamic analogies methods.

In electrical circuits, electrical energy is transmitted through the branches containing resistors, capacitors, inductive coils and other components, and redistributed between branches by means of nodes. Electrical processes, including nonlinear ones, are investigated using known concepts: electric current, voltage, electromotive force. The mathematical description of electrical processes often coincides with the description of processes in objects of a different physical nature, which allows us to replace the study of phenomena in non-electrical systems by studies of analogous phenomena in electrical circuits. Analyzing the components and topological equations of various types of systems, we can detect their dynamic analogies. This makes it possible to use Kirchhoff's laws of electrical engineering and also component equations, in particular, for analyzing bioelectric processes in living tissues and cells. In this case, the cell membrane is represented by a circuit model that includes a capacitive element, and in which the ion channel conductivities are represented in the form of resistive linear and nonlinear components, but nonequilibrium electrochemical processes are described by voltage sources. This approach was applied by Hodgkin-Huxly during the study of bioelectric processes in the nervous tissue [6].

It should be noted that Kirchhoff's laws are basic for analysis of electrical model that reflects bioelectric processes in cells. Application of the Kirchhoff's laws and component equations to electrical circuit leads to system of differential equations. Thus, the study of action potentials and time processes in cardiomyocytes can be based on the system of ordinary differenti- 
al equations for a nonlinear model of an electrical circuit that describes the dynamics of cardiac cells functioning.

\section{Literature review and problem statement}

Nowadays, lab-on-chip technology is an emerging in vitro tool to obtain and study cardiomyocytes typically with human-induced pluripotent stem cells (hiPSCs). These cells can be differentiated into a variety of cardiomyocytes (hiPSC-CMs) and then used for the development of heart disease models, drug screening and tissue regeneration for cell-replacement therapies [7-10]. The key conclusion of these studies is the similarity of electrophysiological properties in hiPSCCMs and human cardiomyocytes.

However, experimental studies using hiPSC-CMs are fairly complex and have advantages, as well as limitations, these latters being mainly related to the maintenance of the environmental and stimulation conditions through time, the small numbers of myocytes produced and their immature nature. As a result information about electrophysiological properties of hiPSC-CMs is limited.

In this scenario, further improvements of methods and tools to study hiPSC-CMs' electrical activity can be provided by computational modeling of electrophysiological properties of cardiomyocytes.

In order to investigate the functional properties of hiPSC-CMs, different electrophysiological technologies are used. Studies $[11,12]$ are based on patch-clamp technique, which is a classical approach to record intracellular electrical activity by inserting a sharp electrode into a cardiomyocyte. Alternatively, multielectrode potential recordings $[10,12]$ allows for studyi$\mathrm{ng}$ the ion channels functions. Contactless imaging methods with use of voltage- and calcium-sensitive fluorescent dyes $[13,14]$ provide multicellular recordings at high spatial resolution for studying morphology of transmembrane potential and intracellular calcium transients during cardiomyocyte's differentiation and drug discovery. The non-invasive, high-resolution method [15], based on genetically encoded calcium and voltage fluorescent reporters, allows for the longterm study of healthy or diseased hiPSC-CMs and, consequently, mechanisms of arrhythmia.

Noteworthy, the study of hiPSC-CM electrophysiological properties allows for the assessment of the functional maturity of the cells. In agreement with [11,13], three action potential types (nodal-, atrial-, or ventricular-like) are generally identified.

A variety of bioengineering strategies, employed with different cell types, can prove the influence of different factors on hESC-CMs functionality. In $[16,17]$ the authors have recorded membrane potential of cardiomyocytes and determinated the action potenti- al's duration after electrical stimulation and under spontaneous beating. In [18] the design and fabrication of a micro-scale cell stimulator, capable of simultaneously providing mechanical, electrical and biochemical stimulation, have been described.

To recapitulate physiological environment of cells in the native myocardium we have recently developed specific heart-on-chip technologies [19]. The proposed device allows for performing electrical and mechanical stimulation and for evaluating the electrophysiological properties of cardiomyocytes. Major attention is paid to the study of the functionality of micro-cardiac tissue: the electrical functionality of control and stimulated constructs was assessed in culture by evaluating the excitation threshold and the maximum capture rate.

However, most of the quoted works describe the characteristics of cardiomyocytes at the sarcomere level, myofilament organization, ion channel expression and intercellular connections during the differentiation process.

The present study is devoted to computational modeling of cardiomyocytes' electrical activity that supplements experimental modeling and can predict the kinetics of contractile force of heart cells at the functional level.

\section{The aim and objectives of the study}

The aim of the paper is to focus on the cardiomyocyte electrophysiological properties at the functional level, including the generation of action potentials, activativation/inactivativation processes in calcium ions channels, the frequency-dependent changes in action potential duration and the intracellular calcium release or uptake, that enables to explain the changes in excitation-contraction coupling of cardiomyocytes.

The experimental modeling of electrical and mechanical processes in cardiac cells, realized on the lab-on-chip platform [19], was a starting point for the development of the purely computational model.

Considering the peculiarities of the research on the heart-on-chip platform, our work was focused on:

- the improvement of the parameters of the mathematical model of cardiomyocytes for reflection order to recapitulate the functional maturity of the heart cells;

- the study of the cardiomyocytes' refractoriness phenomenon;

- the investigation of the processes involved in the cardiomyocytes' electrical restitution. 


\section{Computational modeling}

In this paper, the parallel conductance model was used to modeling of cardiomyocytes' electrophysiological properties at the functional level. This model, based on the approach of Hodgkin-Huxly for nerve tissue, was improved by many scientists specifically to address cardiomyocytes [20,21].

The proposed model [22] accounts for main ionic currents and change of potential for cell's membrane. Independent conductance channels are used for $K^{+}$, $\mathrm{Na}^{+}, \mathrm{Ca}^{2+}$ and leakage.

Transmembrane potential $V_{m}(t)$ can be represented as the sum of alternating component of membrane potential $v_{m}(t)$ and resting potential $V_{m 0}$ :

$$
V_{m}(t)=V_{m 0}+v_{m}(t)
$$

As it follows from the parallel conductance model, the alternating component of the membrane potential is described as:

$$
\begin{aligned}
\frac{d v_{m}}{d t}= & \frac{1}{C_{m}}\left(-I_{K}\left(v_{m}, t\right)-\right. \\
& \left.\quad-I_{N a}\left(v_{m}, t\right)-I_{C a}\left(v_{m}, t\right)-I_{l}+I_{d}\right),
\end{aligned}
$$

where $I_{d}=\left\{\begin{array}{cc}I_{d 0}, & 0<t<T_{d} \\ 0, & t \geq T_{d}\end{array}\right.$ is the depolarizing pulse of current (with amplitude $I_{d 0}$ and duration $T_{d}$ ), which is repeated with a stimulation frequency $\left(F_{s t}\right)$,

$$
\begin{aligned}
I_{K}\left(v_{m}, t\right) & =g_{K}\left(v_{m}, t\right)\left(V_{m 0}+v_{m}+E_{K}\right) \\
I_{N a}\left(v_{m}, t\right) & =g_{N a}\left(v_{m}, t\right)\left(V_{m 0}+v_{m}-E_{N a}\right) \\
I_{C a}\left(v_{m}, t\right) & =g_{C a}\left(v_{m}, t\right)\left(V_{m 0}+v_{m}-E_{C a}\right)
\end{aligned}
$$

are currents for potassium, sodium and calcium, respectively, $I_{l}=g_{l}\left(V_{m 0}+v_{m}+E_{l}\right)$ is the leakage current,

$$
V_{m 0}=\frac{-g_{K 0} E_{K}+g_{N a 0} E_{N a}+g_{C a 0} E_{C a}-g_{l} E_{l}}{g_{K 0}+g_{N a 0}+g_{C a 0}+g_{l}}
$$

is the resting potential, $g_{K 0}, g_{N a 0}$ and $g_{C a 0}$ are the conductances of potassium, sodium and calcium ions at rest; $E_{K}, E_{N a}$ and $E_{C a}$ are Nernst potentials of potassium, sodium and calcium respectively; $g_{l}$ is the leakage conductivity through the membrane; $E_{l}$ is the electromotive force of source, which simulates Nernst potential for chlorine ions, leakage and other factors that affect the membrane potential at rest.

Membrane conductances for $\mathrm{K}^{+}, \mathrm{Na}^{+}, \mathrm{Ca}^{2+}$ channels are described by the following equations:

$$
\begin{aligned}
g_{K}\left(u_{m}, t\right) & =g_{K_{\max }} n^{4}\left(v_{m}, t\right), \\
g_{N a}\left(v_{m}, t\right) & =g_{N a \max } m^{3}\left(v_{m}, t\right) h\left(v_{m}, t\right), \\
g_{C a}\left(v_{m}, t\right) & =g_{C a_{\max }} d\left(v_{m}, t\right) f\left(v_{m}, t\right),
\end{aligned}
$$

where $g_{K \max }, g_{N a \max }$ and $g_{C a \max }$ are conductances for potassium, sodium and calcium ions, respectively, in the case that all the channels for this type of ions are in the open state; $n$ is activation function of $K^{+}$channels; $m$ is activation function and $h$ is inactivation function for $\mathrm{Na}^{+}$channels; $d$ is activation function and $f$ is inactivation function for $\mathrm{Ca}^{2+}$ channels.

Consequently, conductances and currents for $K^{+}$, $\mathrm{Na}^{+}, \mathrm{Ca}^{2+}$ ions are determined by five gating variables $n, m, h, d$, and $f$, which are solutions of the differential equations:

$$
\begin{array}{ll}
\frac{d n}{d t}=\frac{n_{\infty}-n}{\tau_{n}}, & \frac{d m}{d t}=\frac{m_{\infty}-m}{\tau_{m}}, \\
\frac{d h}{d t}=\frac{h_{\infty}-h}{\tau_{h}}, & \frac{d d}{d t}=\frac{d_{\infty}-d}{\tau_{d}}, \\
\frac{d f}{d t}=\frac{f_{\infty}-f}{\tau_{f}}, &
\end{array}
$$

where $n_{\infty}, m_{\infty}$ and $d_{\infty}$ are the steady-state value of activation function for potassium, sodium and calcium channels respectively; $h_{\infty}$ and $f_{\infty}$ are the steady-state values of inactivation function for sodium and calcium channels; $\tau_{n}, \tau_{m}$ and $\tau_{d}$ are the relaxation periods of activation for potassium, sodium and calcium channels; $\tau_{h}$ and $\tau_{f}$ are the relaxation periods of inactivation for sodium and calcium channels.

Equations (1) and (3) define the Cauchy problem for the system of ordinary differential equations with the initial conditions:

$$
\begin{aligned}
& v_{m}(0)=0 ; \quad n(0)=n_{0} ; \quad m(0)=m_{0} ; \\
& d(0)=d_{0} ; \quad h(0)=h_{0} ; \quad f(0)=f_{0},
\end{aligned}
$$

where $n_{0}, m_{0}, d_{0}, h_{0}$ and $f_{0}$ are the steady-state values of activation and inactivation function if alternating component of membrane potential is equal to zero.

The attained system is a set of stiff differential equations. Consequently, to solve Cauchy problem, the implicit methods of integration is used [23].

Using the predictor-corrector method, step $\Delta t$ in the initial segment of integration should not be too large ( $\Delta t<T_{d}$, where $T_{d}$ is duration of the depolarizing pulse).

A detailed description of the functions and numerical values for parameters of the proposed model is given in [22].

\section{Numerical experiments}

Numerical experiments to model AP in heart cells were performed in Matlab environment. The generation of AP and ion currents for ventricular and atrial cardiomyocytes was simulated. The study accounts for the cardiomyocyte electrical properties such as the refractory period, the maximum capture rate and the restitution during stimulation.

\subsection{Action potentials and main currents for cardiomyocytes}

Simulated action potentials for ventricular and atrial cardiomyocytes (Fig. 1) were obtained in [22]. 


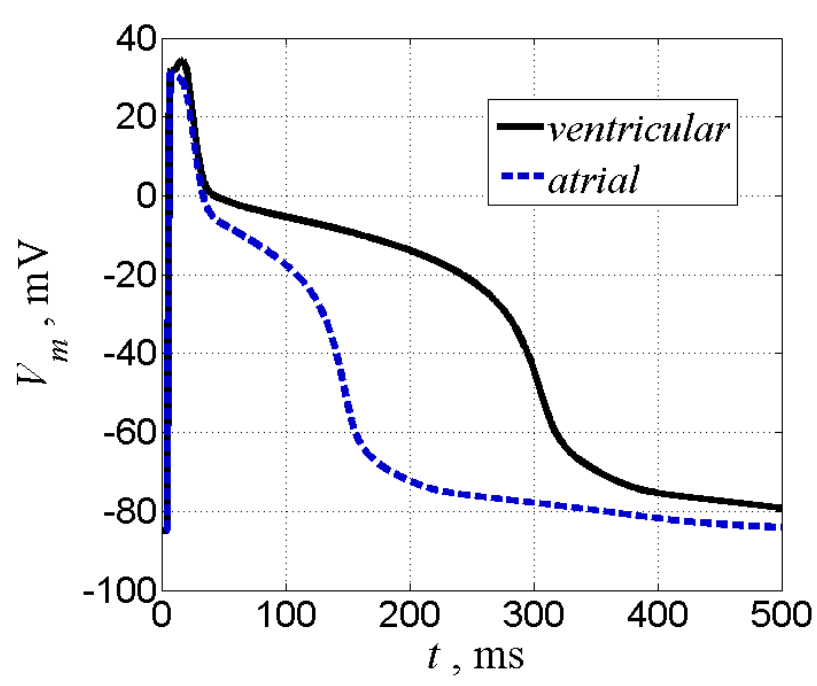

Fig. 1. Simulated action potentials for ventricular and atrial cardiomyocytes. Modified from [22]. Arrows indicate the time point of $90 \%$ of AP duration (APD90).

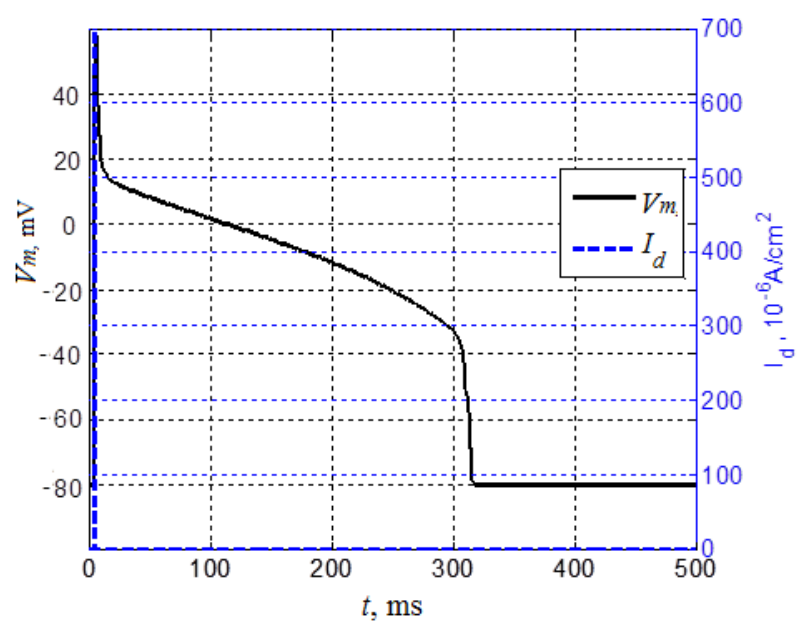

(a)

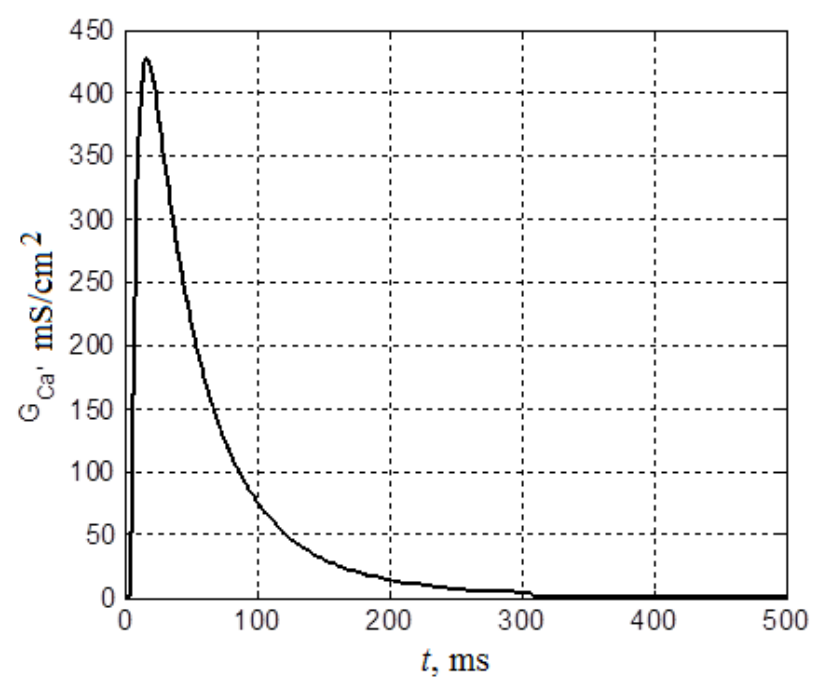

(c)
In accordance with the theoretical information [20] each action potential has three characteristic phases: depolarization, plateau and repolarization.

Depolarization phase is determined by a sharp increase of AP amplitude initiated by the growth of membrane permeability for sodium ions. Plateau phase describes the slow decline of action potential, because the inward (slow calcium) and outward (potassium) currents are nearly balanced (Fig. 2a). Repolarization phase is characterized by the faster decline of AP, which could be explained by inactivating of calcium channels and activating of the potassium channels [20].

According to the proposed model [22], currents and conductances for potassium, sodium, calcium ions were calculated and presented for ventricular cardiomyocytes in Fig. 2b-d (currents of $\mathrm{K}^{+}, \mathrm{Na}^{+}, \mathrm{Ca}^{2+}$ ions, conductance of $\mathrm{Ca}^{2+}$ channels and conductance of $\mathrm{K}^{+}, \mathrm{Na}^{+}$channels, respectively).

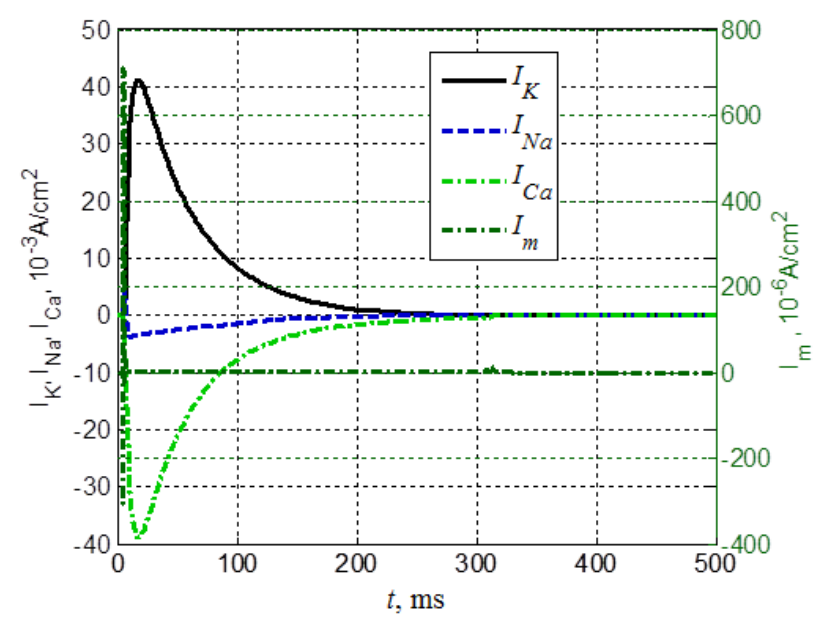

(b)

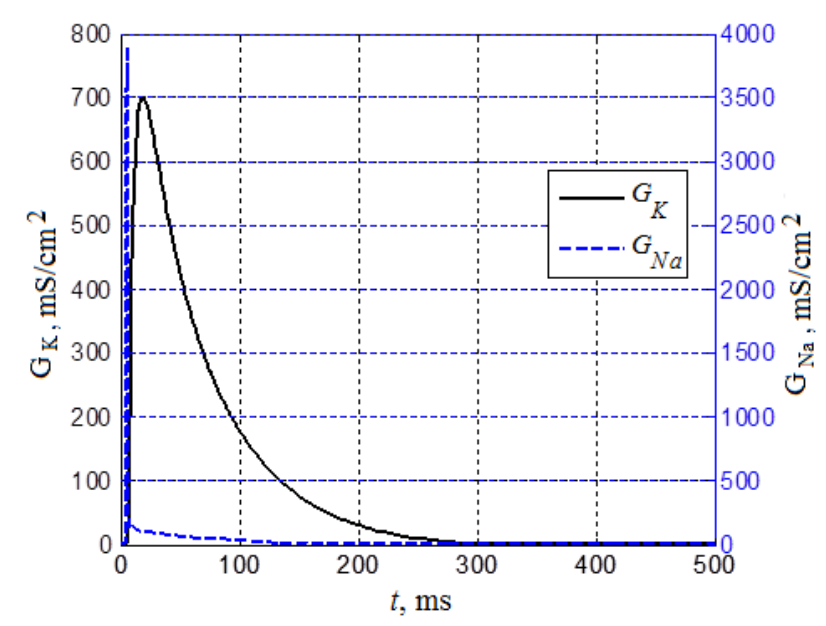

(d)

Рис. 2. Simulated action potential (a), currents of $\mathrm{K}^{+}, \mathrm{Na}^{+}, \mathrm{Ca}^{2+}$ ions (b), conductance of $\mathrm{Ca}^{2+}$ channels (c), conductance of $\mathrm{K}^{+}, \mathrm{Na}^{+}$channels (d) of ventricular cardiomyocytes. 
In numerical experiments the stimulation frequency $F_{s t}$ (stimulation cycle length $(C L)$ ) varied from $1 \mathrm{~Hz}$ $(1000 \mathrm{~ms})$ to $6 \mathrm{~Hz}(167 \mathrm{~ms})$. Durations of action potentials (APD) were measured as the interval from beginning of action potential to the time point of $90 \%$ of AP duration (APD90) (Fig. 1).

\subsection{Refractory period and maximum capture rate of cardiomyocytes}

It is known [20] that refractoriness of cardiomyocytes is determined by the refractory period (RP), which is a period of time when another AP cannot be generated as the cell needs to recover from the previous AP. This peculiarity of AP takes place due to the inactivation of $\mathrm{Na}^{+}$and $\mathrm{Ca}^{2+}$ channels.

Three action potentials are chosen as representative APs at various stimulation frequencies $(2.5 \mathrm{~Hz}, 3 \mathrm{~Hz}$, $3.25 \mathrm{~Hz}, 3.27 \mathrm{~Hz}$ ). Fig. 3a-c demonstrates changing of APD with increasing $F_{s t}$ (decreasing $C L$ ), and Fig. 3d $\left(C L=306 \mathrm{~ms}, F_{s t}=3.27 \mathrm{~Hz}\right)$ shows the case, when the myocyte fails to capture AP. Therefore, the maximum capture rate of cardiomyocyte is achieved under the stimulation frequency $F_{s t}=3.27 \mathrm{~Hz}$.

\subsection{Electrical restitution of cardi- omyocytes}

Different authors have studied the electrical restitution that is an intrinsic heart property of change of action potential duration (APD) according to heart rate (HR) [24-28]. The relationships between APD of cardiomyocytes and $F_{s t}$ (or $C L$ ) or, more correctly, preceding diastolic intervals $(D I)$ are investigated. Usually, the preceding $D I$ is determined as the time interval between full cardiac repolarization and the growth of the next AP (during cycle length).

The APD shortens with decreasing $C L$ length and thus with decreasing $D I$. It is thought that restitution takes place because calcium current does not fully recover at short $D I$, which leads to short APD at short $D I$.

Electrical restitution data were simulated using the dynamic restitution protocol (DYRT) [24], in which stimulation impulses were generated with various stimulation frequencies $F_{s t}$ or cycle lengths $C L$. According to this protocol cardiomyocytes were stimulated in the physiologically determined frequency range with increasing $F_{s t}$ incrementally until the myocyte fails to capture AP, that means refractory period has been reached and maximum capture rate of cardiomyocytes has been obtained.

The responses (AP and currents) from ventricular cardiomyocytes stimulated at different $F_{s t}$ were investigated. Electrical stimulation started at $1 \mathrm{~Hz}$ and increased up to $6 \mathrm{~Hz}$ with assessment of the maximum capture rate. The ventricular myocyte failed to capture
$\mathrm{AP}$ at stimulation frequency $F_{s t}=3.27 \mathrm{~Hz}(C L=306$ $\mathrm{ms})$.

Similar action potentials and currents in atrial cardyomyocytes were obtained varying $F_{s t}$. However, the atrial myocyte failed to capture AP at higher stimulation frequency compared to the stimulation frequency of ventricular myocyte (at frequency $F_{s t}=5.125 \mathrm{~Hz}$, when maximum capture rate is achieved).

APDs for atrial and ventricular cardyomyocytes shortened at increasing stimulation frequencies and decreasing cycle lengths (Fig. 4). Mean APD90 at each stimulation frequency (cycle length) was obtained by averaging of 20 consecutive steady-state APs.

The restitution curves of mean APD90 for atrial and ventricular cardyomyocytes are shown as functions of stimulation frequency (Fig. 4a) and as functions of cycle length, the inverse of stimulation frequency (Fig. 4b).

Calcium current mean value for atrial and ventricular cardyomyocytes decreases with increasing of stimulation frequency (Fig. 5a) and with decreasing of cycle length (Fig. 5b). Mean value of $I_{C a}$ at each stimulation frequency (cycle length) was obtained by averaging of $I_{C a}$ during 20 consecutive action potentials.

\section{Discussion}

Many studies have been performed in order to investigate the changes of APDs, which likely plays an important role in arrhythmogenesis. According to the overview of published data [24-28], the normal electrical restitution curve has three main phases: a steep recovery at the shortest either CLs or DIs, a transient decline at middle CLs (DIs), and a final rise to a plateau at long $C L s(D I s)$. Furthermore, the maximum slope of the restitution curve is crucial in determining the arrhythmogenic properties of cardiomyocytes. Under maximum slope of the curve more than 1 the fluctuation of cardiomyocyte's electrical activity occur thus creating the heart unstability. In addition, rate dependent alterations of APD are markers of atrial and ventricular arrhythmias.

Dependences APD against $F_{s t}$ (Fig. 4a) and APD against $C L$ (Fig. 4b) generate the APD electrical restitution curves, which also have several phases with the various steepness. The maximum slope of the curves arises due to refractoriness of cardiomyocytes and corresponds to the range of maximum capture rate. Therefore the analysis of the electrical restitution curves allows for explaining the difference between behavior of atrial and ventricular cardiomyocytes.

The results of the numerical experiments were analyzed and compared with the experimental results, based on the lab-on-chip technology [19]. In the computational analysis the same research protocol was used as for the experimental study. According to the 


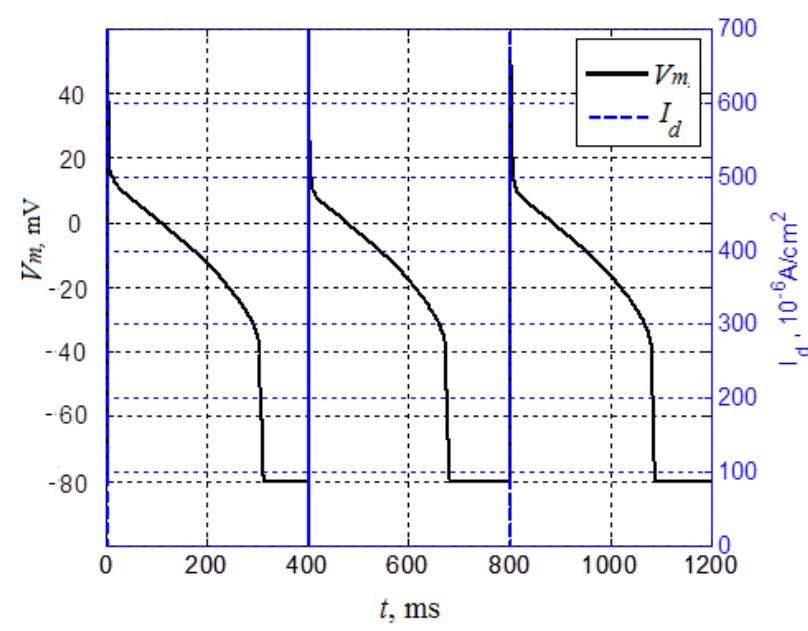

(a)

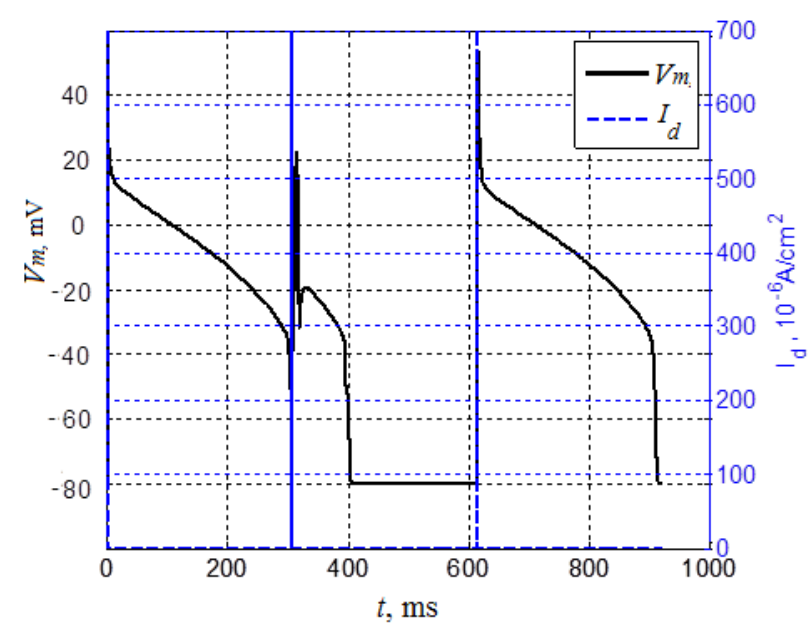

(c)

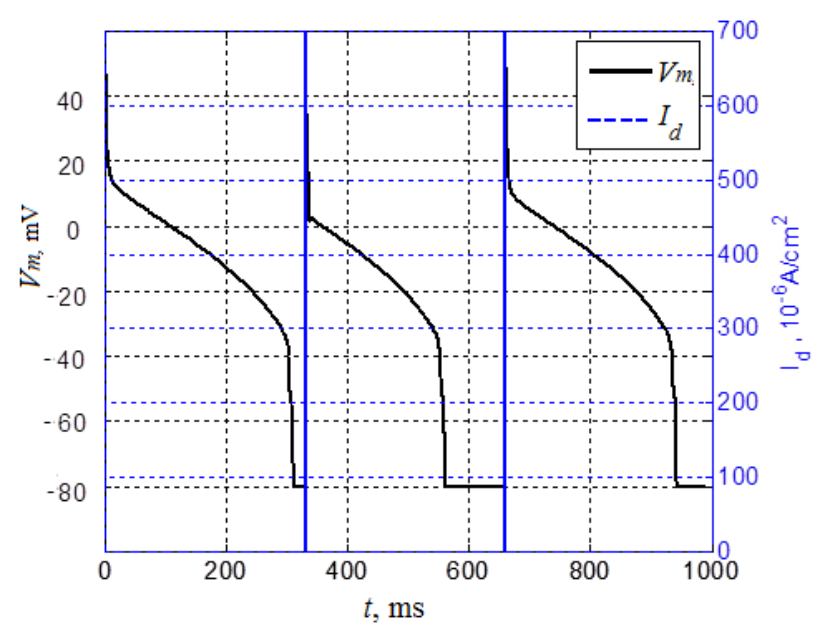

(b)

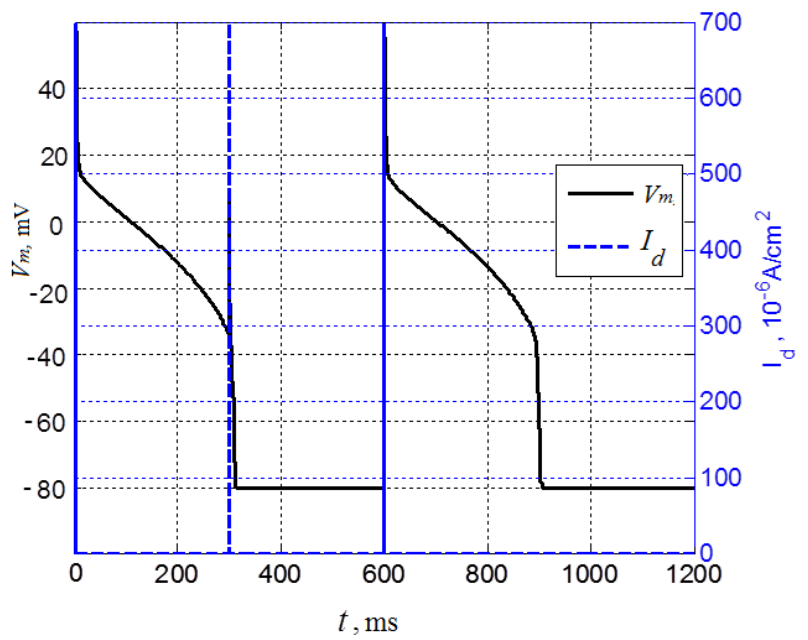

(d)

Рис. 3. Change of action potential duration (APD) during stimulation process: $F_{s t}=2.5 \mathrm{~Hz}(C L=400 \mathrm{~ms})(\mathrm{a})$, $F_{s t}=3 \mathrm{~Hz}(C L=333 \mathrm{~ms})(\mathrm{b}), F_{s t}=3.25 \mathrm{~Hz}(C L=308 \mathrm{~ms})(\mathrm{c}), F_{s t}=3.27 \mathrm{~Hz}(C L=306 \mathrm{~ms})(\mathrm{d})$.

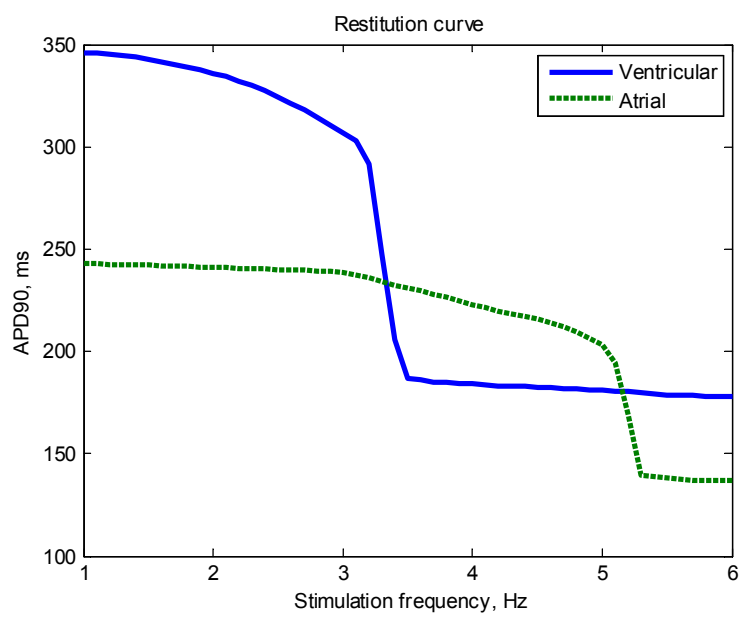

(a)

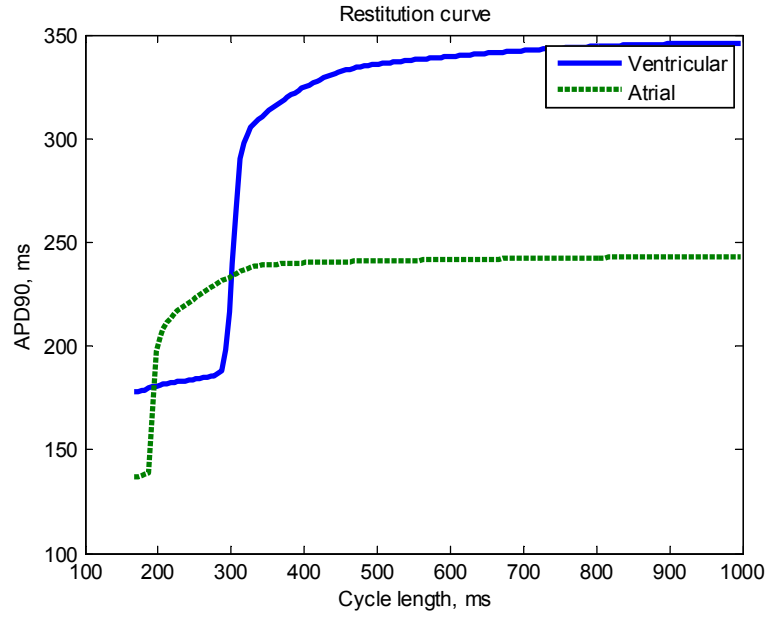

(b)

Рис. 4. Electrical restitution curves for atrial and ventricular cardiomyocytes: APD90 against $F_{s t}(\mathrm{a})$, APD90 against $C L(\mathrm{~b})$. 


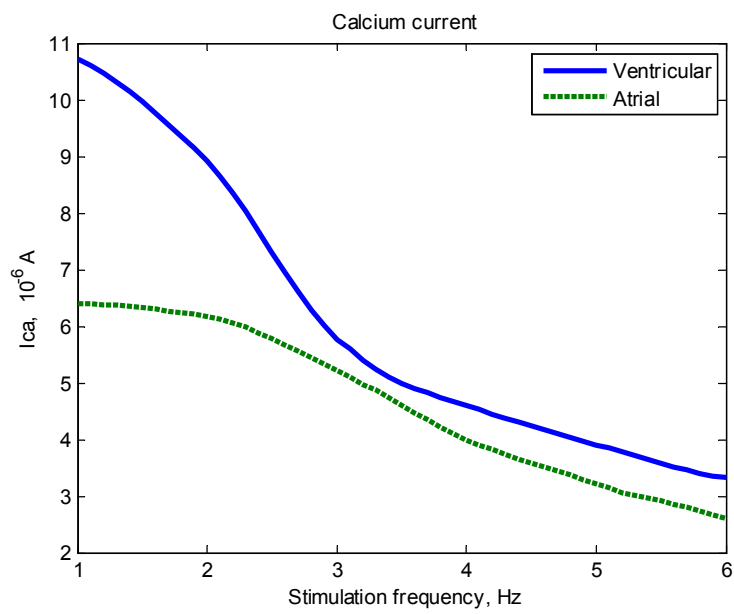

(a)

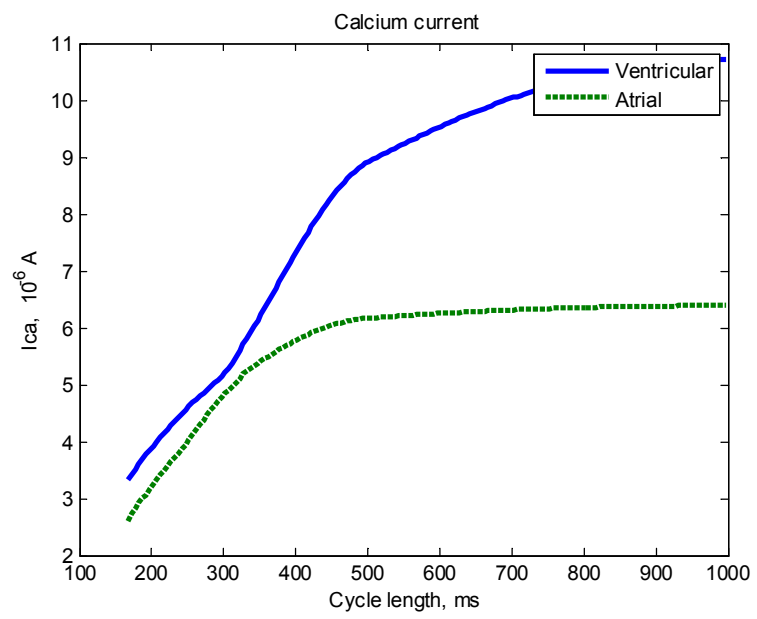

(b)

Рис. 5. Dependence of calcium current for atrial and ventricular cardiomyocytes:

ICa against $F_{s t}(\mathrm{a})$, ICa against $C L(\mathrm{~b})$.

dynamic restitution protocol, cardiomyocytes were stimulated at the physiologically determined frequency range with increasing $F_{s t}$ incrementally until the myocyte fails to capture AP. This means that the refractory period has been reached and the maximum capture rate of cardiomyocytes has been obtained. During experimental results, the values of maximum capture rate were obtained in the frequency range from $3 \mathrm{~Hz}$ to $5.5 \mathrm{~Hz}$. This variability can be explained by the presence of different types of cardiomyocytes (atrial- or ventricular-like) after the differentiation process from human-induced pluripotent stem cells.

The calculated restitution curves allows for identifying the maximum slopes, which determine the arrhythmogenic properties of heart cells (in which cardiomyocytes can change the beating rate). Moreover, there is supportive evidence that drugs, which reduce restitution slope, play a protective role against arrhythmias. Accordingly, computational experiments can effectively support the design of new experiments with hiPSC-CMs.

\section{Conclusions}

Computational simulation of cardiomyocytes' electrophysiological properties may help to explain the shape of the electrical restitution curves at various repolarization levels for atrial and ventricular cardiomyocytes and to predict the kinetics of intracellular calcium and contractile force. The proposed model allowed us to detect those regions characterized by elevated slopes, capable to confer arrhythmogenic properties of cardiomyocytes. Computational results are useful to interpret experimental results with hiPSC$\mathrm{CMs}$ on the lab-on-chip platform and to propose the new design of the experiments for personalized studies of heart disease. The aforementioned research can allow monitoring the changes in AP, calcium current properties of hiPSC-CMs and the development of arrhythmias in response to application of various drugs or different stimulation modes. The method of dynamic analogies used in the work allows us to generalize this approach for studying the electrical properties of cardiomocytes and for investigation of the electromechanical model of nonequilibrium processes in the myocardial tissues. Future directions of research related to the simulation of cardiomyocyte's activity should be focused on electro-mechanical coupling, electrical and mechanical stimulation, and spontaneous beating

\section{Acknowledgment}

The study was supported by EU-financed Horizon 2020 project AMMODIT (Approximation Methods for Molecular Modeling and Diagnosis Tools) - Grant Number MSCA-RISE 645672.

\section{References}

[1] Olson H.F. (2005) Dynamical Analogies. Van Nostrand's Scientific Encyclopedia. DOI: 10.1002/0471743984.vse2719

[2] Sigorskii V.P. (1977) Matematicheskii apparat inzhenera [The mathematical tools of the engineer], Kiev, Tekhnika Publ., 768 p. (in Russian)

[3] Hogan N. and Breedveld P. (2005) The Physical Basis of Analogies in Physical System Models. Mechatronics, pp. 8-1. DOI: $10.1201 / 9781420037241 . c h 8$

[4] Fu K., Moreno D., Yang M. and Wood K.L. (2014) BioInspired Design: An Overview Investigating Open Questions From the Broader Field of Design-by-Analogy. Journal of Mechanical Design, Vol. 136, Iss. 11, pp. 111102. DOI: $10.1115 / 1.4028289$

[5] Glier M.W., McAdams D.A. and Linsey J.S. (2011) Concepts in Biomimetic Design: Methods and Tools to Incorporate Into a Biomimetic Design Course. Volume 7: 5th International Conference on Micro- and Nanosystems; 
8th International Conference on Design and Design Education; 21st Reliability, Stress Analysis, and Failure Prevention Conference. DOI: 10.1115/detc2011-48571

[6] Hodgkin A.L. and Huxley A.F. (1952) A quantitative description of membrane current and its application to conduction and excitation in nerve. The Journal of Physiology, Vol. 117, Iss. 4, pp. 500. DOI: 10.1113/jphysiol.1952.sp004764

[7] Ellis B.W., Acun A., Can U.I. and Zorlutuna P. (2017) Human iPSC-derived myocardium-on-chip with capillarylike flow for personalized medicine. Biomicrofluidics, Vol. 11, Iss. 2, pp. 024105. DOI: 10.1063/1.4978468

[8] Liang P., Lan F., Lee A.S., Gong T., Sanchez-Freire V., Wang Y., Diecke S., Sallam K., Knowles J.W., Wang P.J., Nguyen P.K., Bers D.M., Robbins R.C. and Wu J.C. (2013) Drug Screening Using a Library of Human Induced Pluripotent Stem Cell-Derived Cardiomyocytes Reveals DiseaseSpecific Patterns of Cardiotoxicity. Circulation, Vol. 127, Iss. 16, pp. 1677. DOI: 10.1161/circulationaha.113.001883

[9] Robinton D.A. and Daley G.Q. (2012) The promise of induced pluripotent stem cells in research and therapy. Nature, Vol. 481, Iss. 7381, pp. 295. DOI: $10.1038 /$ nature 10761

[10] Zwi L., Caspi O., Arbel G., Huber I., Gepstein A., Park I. and Gepstein L. (2009) Cardiomyocyte Differentiation of Human Induced Pluripotent Stem Cells. Circulation, Vol. 120, Iss. 15, pp. 1513. DOI: $10.1161 /$ circulationaha. 109.868885

[11] Ma J., Guo L., Fiene S.J., Anson B.D., Thomson J.A., Kamp T.J., Kolaja K.L., Swanson B.J. and January C.T. (2011) High purity human-induced pluripotent stem cellderived cardiomyocytes: electrophysiological properties of action potentials and ionic currents. American Journal of Physiology-Heart and Circulatory Physiology, Vol. 301, Iss. 5, pp. H2006. DOI: 10.1152/ajpheart.00694.2011

[12] Richardson E.S. and Xiao Y. (2010) Electrophysiology of Single Cardiomyocytes: Patch Clamp and Other Recording Methods. Cardiac Electrophysiology Methods and Models, pp. 329. DOI: $10.1007 / 978-1-4419-6658-2 \_16$

[13] Blazeski A., Zhu R., Hunter D.W., Weinberg S.H., Boheler K.R., Zambidis E.T. and Tung L. (2012) Electrophysiological and contractile function of cardiomyocytes derived from human embryonic stem cells. Progress in Biophysics and Molecular Biology, Vol. 110, Iss. 2-3, pp. 178. DOI: 10.1016/j.pbiomolbio.2012.07.012

[14] Lee P., Klos M., Bollensdorff C., Hou L., Ewart P., Kamp T.J., Zhang J., Bizy A., Guerrero-Serna G., Kohl P., Jalife J. and Herron T.J. (2012) Simultaneous Voltage and Calcium Mapping of Genetically Purified Human Induced Pluripotent Stem Cell-Derived Cardiac Myocyte Monolayers. Circulation Research, Vol. 110, Iss. 12, pp. 1556. DOI: 10.1161/circresaha.111.262535

[15] Shinnawi R., Huber I., Maizels L., Shaheen N., Gepstein A., Arbel G., Tijsen A. and Gepstein L. (2015) Monitoring Human-Induced Pluripotent Stem Cell-Derived Cardiomyocytes with Genetically Encoded Calcium and Voltage Fluorescent Reporters. Stem Cell Reports, Vol. 5, Iss. 4, pp. 582. DOI: $10.1016 / \mathrm{j}$. stemcr.2015.08.009

[16] Hansen A., Eder A., Bonstrup M., Flato M., Mewe M., Schaaf S., Aksehirlioglu B., Schworer A., Uebeler J. and Eschenhagen T. (2010) Development of a Drug Screening Platform Based on Engineered Heart Tissue. Circulation Research, Vol. 107, Iss. 1, pp. 35. DOI: 10.1161/circresaha.109.211458
[17] Werdich A.A., Lima E.A., Ivanov B., Ges I., Anderson M.E., Wikswo J.P. and Baudenbacher F.J. (2004) A microfluidic device to confine a single cardiac myocyte in a sub-nanoliter volume on planar microelectrodes for extracellular potential recordings. Lab on a Chip, Vol. 4, Iss. 4 , pp. 357. DOI: 10.1039/b315648f

[18] Pavesi A., Adriani G., Rasponi M., Zervantonakis I. K., Fiore G. B. and Kamm R. D. (2015) Controlled electromechanical cell stimulation on-a-chip. Scientific Reports, Vol. 5, Iss. 1. DOI: 10.1038/srep 11800

[19] Marsano A., Conficconi C., Lemme M., Occhetta P., Gaudiello E., Votta E., Cerino G., Redaelli A. and Rasponi M. (2016) Beating heart on a chip: a novel microfluidic platform to generate functional 3D cardiac microtissues. Lab on a Chip, Vol. 16, Iss. 3, pp. 599. DOI: $10.1039 / \mathrm{c} 51 \mathrm{c} 01356 \mathrm{a}$

[20] Plonsey R. and Barr R.C. (2007) Cardiac Electrophysiology. Bioelectricity, p. 267. DOI: 10.1007/978-0-38748865-3_9

[21] Luo C.H. and Rudy Y. (1994) A dynamic model of the cardiac ventricular action potential. I. Simulations of ionic currents and concentration changes. Circulation Research, Vol. 74, Iss. 6, pp. 1071. DOI: 10.1161/01.res.74.6.1071

[22] Ivanko K., Ivanushkina N. and Prokopenko Y. (2017) Simulation of action potential in cardiomyocytes. 2017 IEEE 37th International Conference on Electronics and Nanotechnology (ELNANO). DOI: 10.1109/elnano.2017.7939777

[23] Spiteri R.J. and Dean R.C. (2008) On the Performance of an Implicit-Explicit Runge-Kutta Method in Models of Cardiac Electrical Activity. IEEE Transactions on Biomedical Engineering, Vol. 55, Iss. 5, pp. 1488. DOI: 10.1109/tbme.2007.914677

[24] Khuwaileh R. A. (2016) Electrical restitution and action potential repolarisation studies in acutely isolated cardiac ventricular myocytes, University of Leicester.

[25] Traxel S.J. and Patwardhan A. (2009) A novel method to quantify contribution of electrical restitution to alternans of repolarization in cardiac myocytes: a simulation study. FASEB Journal, Vol. 23, No. 1, Suppl. 624.7.

[26] Shattock M.J., Park K.C., Yang H., Yang H., Niederer S., MacLeod K.T. and Winter J. (2017) Restitution slope is principally determined by steady-state action potential duration. Cardiovascular Research, Vol. 113, Iss. 7, pp. 817. DOI: $10.1093 / \mathrm{cvr} / \mathrm{cvx} 063$

[27] Kanaporis G. and Blatter L.A. (2017) Alternans in atria: Mechanisms and clinical relevance. Medicina, Vol. 53, Iss. 3, pp. 139. DOI: 10.1016/j.medici.2017.04.004

[28] Orini M., Taggart P., Srinivasan N., Hayward M. and Lambiase P.D. (2016) Interactions between Activation and Repolarization Restitution Properties in the Intact Human Heart: In-Vivo Whole-Heart Data and Mathematical Description. PLOS ONE, Vol. 11, Iss. 9, pp. e0161765. DOI: 10.1371/journal.pone.0161765 


\section{Обчислювальна модель електрофізіо-} логічних властивостей кардіоміоцитів

\author{
Іванушкіна Н. Г., Іванъко К. О., Прокопенко Ю. В., \\ Редаеллі А., Тимофеєв В. I., Вісоне Р.
}

В даному дослідженні метод електричних аналогій був використаний для аналізу біоелектричних динамічних процесів у кардіоміоцитах. Цей метод дозволив замінити вивчення явищ у неелектричних системах дослідженнями аналогічних явищ в електричних колах. Вивчення часових процесів у серцевих клітинах грунтувалось на дослідженні системи звичайних диференціальних рівнянь для електричної схеми, реакції якої $\epsilon$ аналогічними процесам в клітинах серця. У цьому дослідженні основна увага приділена комп'ютерному моделюванню електричної активності серця на клітинному рівні. У роботі вивчено електрофізіологічні властивості кардіоміоцитів: рефрактерний період, максимальна швидкість захоплення та електрична реституція. Обчислювальне моделювання потенціалу дії та струмів для іонів $\mathrm{K}^{+}, \mathrm{Na}^{+}, \mathrm{Ca}^{2+}$ у кардіоміоцитах проведено за допомогою моделі паралельних провідностей. Ця модель грунтується на припущенні про наявність незалежних каналів для іонів $\mathrm{K}^{+}, \mathrm{Na}^{+}, \mathrm{Ca}^{2+}$, а також їх витоку через мембрану серцевої клітини. Кожна гілка електричного кола моделі відображає внесок одного типу іонів у загальний мембранний струм. У роботі досліджено криві електричної реституції для кардіоміоцитів шлуночків та передсердь. Запропонована модель дозволила ідентифікувати на кривих реституції ділянки з максимальним нахилом, які мають вирішальне значення у розвитку серцевих аритмій. Отримано залежність середнього значення кальцієвого струму від частоти стимуляції для кардіоміоцитів передсердь та шлуночків. Аналіз кінетики іонів кальцію за різними протоколами зовнішніх впливів може бути корисним для прогнозування скорочувальної сили кардіоміоцитів. Результати розрахунків можна буде застосувати для інтерпретації експериментальних результатів, що отримано в дослідженнях кардіоміоцитів з використанням технології "лабораторія на чіпі", а також в розробці нових експериментів з кардіоміоцитами для скринінгу ліків, клітинної терапії та персоналізованих досліджень хвороб серця.

Ключові слова: метод електричних аналогій; кардіоміоцит; потенціал дії; модель паралельних провідностей; крива електричної реституції; лабораторія на чіпі

\section{Вычислительная модель электрофизи- ологических свойств кардиомиоцитов}

\author{
Иванушкина Н. Г., Иванъко Е. О., \\ Прокопенко Ю. В., Редаэлли А., Тимофеев В.И., \\ Висонэ $P$.
}

В данном исследовании метод электрических аналогий применён для анализа биоэлектрических динамических процессов в кардиомиоцитах. Этот метод позволил заменить изучение явлений в неэлектрических системах исследованиями аналогичных явлений в электрических цепях. Изучение временных процессов в кардиомиоцитах основано на исследовании системы обыкновенных дифференциальных уравнений для электрической цепи, рекции которой аналогичны процесам в клетках сердца. В данном исследовании основное внимание уделено компьютерному моделированию электрической активности сердца на клеточном уровне. В работе изучены электрофизиологические свойства кардиомиоцитов: рефрактерный период, максимальная скорость захвата и электрическая реституция. Вычислительное моделирование потенциала действия и токов для ионов $\mathrm{K}^{+}, \mathrm{Na}^{+}$, $\mathrm{Ca}^{2+}$ в кардиомиоцитах проведено с использованием модели параллельных проводимостей. Данная модель основана на предположении наличия независимых каналов для ионов $\mathrm{K}^{+}, \mathrm{Na}^{+}, \mathrm{Ca}^{2+}$, а также их протекания через мембрану сердечной клетки. Каждая ветвь электрической схемы модели отражает вклад одного типа ионов в общий ток мембраны. В работе исследованы кривые электрической реституции для желудочковых и предсердных кардиомиоцитов. Предложенная модель позволила идентифицировать на кривых реституции участки с максимальным наклоном, которые имеют решающее значение в развитии сердечных аритмий. Получены зависимости тока кальция от частоты стимуляции для кардиомиоцитов предсердий и желудочков. Анализ кинетики ионов кальция при различных протоколах внешних воздействий может быть полезен для прогноза сократительной силы кардиомиоцитов. Результаты вычислений могут применяться для интерпретации экспериментальных результатов, полученных при исследовании кардиомиоцитов с использованием платформы “лаборатория на чипе", а также при проектировании новых экспериментов с кардиомиоцитами для скрининга лекарств, клеточной терапии и персонализированных исследований заболеваний сердща.

Ключевые слова: метод электрических аналогий; кардиомиоцит; потенциал действия; модель параллельных проводимостей; кривая электрической реституции; платформа "лаборатория на чипе" 